\title{
Are Transient X-Ray Sources Cataclysmic Binaries?
}

Transient X-ray sources are characterized by a rapid rise in intensity over a few days to a maximum, which may last for several months and a subsequent slow decrease. It is not known whether the bursts occur periodically. The hypothesis most widely used is the eccentric binary. The system is assumed to consist of a normal star and a compact object (white dwarf, neutron star, black hole) in an orbit of very high eccentricity. The X-ray emission is produced by accretion of a stellar wind from the star onto the compact object. Appreciable accretion occurs only during a short time around the periastron. Bursts occur regularly with the orbital period. One of them, A 0620-00, could be identified optically with Nova Monocerotis in 1975. Superimposed on the decline of optical brightness by approximately $0.5 \mathrm{~m}$ in 1 month Duerbeck and Walter [1] found roughly sinusoidal fluctations of $15-20 \%$ with a period of 3.92 days. Subsequently Matilsky [2] detected also varia- tions in the $\mathrm{X}$-ray region with a period of roughly 8 days. This period was proposed recently also for the visible region by Chevalier et al. [3]. If this periodwhich is the correct one is not clear at present-is identified with the orbital period, the eccentric binary model is excluded for this system. A consistent model would be $[1,4]$ as follows.

A compact object in nearly circular orbit accretes matter overflowing the Roche lobe after an outburst of the companion which is a main-sequence or subgiant latetype star. The model is almost the same as for dwarf novae, which show a similar behavior as transient $\mathrm{X}$-ray sources, but in the optical region alone. The difference is that in dwarf novae the compact companion is a white dwarf, whereas here one might expect a neutron star or a black hole on account of the X-ray emission. If this model applies also to the other transient X-ray sources, this would be very important for our understanding of binary evolution and the theory of supernovae. All regular binary X-ray sources have almost circular orbits. Of course there is still the possibility that the period detected is not the orbital period, or that A $0620-00$ is of a different character than the rest of the transient X-ray sources. In fact its $\mathrm{X}$-ray spectrum is soft, those of the others are hard. However, the cataclysmic binary model discussed here would not encounter the difficulties of the eccentric binary model, where one of the major problems is the strong asymmetry of the luminosity curve.

M. Reinhardt Astronomisches Institut der Ruhr-Universität Bochum

1. Duerbeck, H.W., Walter, K.; Astron. Astrophys. 48, 141 (1976)

2. Matilsky, T.: IAU Circ. 2949 (1976)

3. Chevalier, C., et al.: IAU Circ. 2957 (1976)

4. Avni, Y., et al.: Mon. Not. Roy Astr. Soc. 175, 297 (1976)

\section{Element 114 in Meteoriten?}

In primitiven Meteoriten wie dem 1969 in Mexiko gefallenen Chrondriten „Allende“ oder dem Meteoriten „Renazzo“ findet man zahlreiche Xenon-Isotope. Bestimmte Anteile dieses Xenon-Vorkommens haben eine charakteristische, vom Rest deutlich unterschiedene Isotopenzusammensetzung. Diese Anteile lassen sich durch stufenweises Erhitzen isolieren oder kommen - wie jetzt von "Allende" berichtet wurde $[1,2]$ - nur konzentriert in bestimmten Bruchteilen (weniger als $0,5 \%$ ) des Meteoriten vor. In Meteoriten erwartet man aus dem Sonnennebel eingefangene Edelgase. Da für diesen Einfangprozeß die Isotopentzusammensetzung des Xenons irrelevant ist, können isolierte Xenonpartien mit vom Rest unterschiedener Isotopenverteilung nicht aus dieser Quelle stammen. Nach einer an sich plausiblen Theorie sind diese Xenon-Anteile das Resultat der spontanen Spaltung schwerer Elemente, die anfangs im Meteoriten lokalisiert in festen Verbindungen vorlagen. Untersuchungen der Details des Xenonvorkommens haben gezeigt, daß von den bekannten schweren Isotopen keines als Ursprungselement der isolierten Xenonisotope in Frage kommt. Verträglich sind alle Daten jedoch mit der Annahme, daß das Ursprungselement die Kernladung 114 und die Neutronenzahl 184 besitzt. In der Tat gehört dieses Isotop zu den von den Kernphysikern als relativ langlebig vorhergesagten Transuranen [3], zur ,Insel der Stabilität“. Nach kernphysikalischen Vorsteilungen könnte dieses Element durchaus die erforderliche Lebensdauer von $10^{7}-10^{8}$ Jahren besitzen. Solch ein Element wäre bis heute restlos zerfallen; sein früheres Vorkommen müßte aus seinen Spuren erschlossen werden. Die generelle Plausibilität der hier beschriebenen These sollte jedoch nicht vergessen lassen, daß der Schluß auf genau das Element 114 von der korrekten Interpretation zahlreicher Details abhängt. Da es zudem konkurrierende Theorien über den Ursprung des isolierten Xenons in Allende und Renazzo gibt, wird ein Kernphysiker die Aussagen von [1] und [2] zumindest nicht als vollständigen Beweis für die große Lebensdauer des Isotops 298 des Elements 114 ansehen. Nach E. Anders [1] ist die Wahrscheinlichkeit, da 3 das Element 114 von ihm und seinen Mitarbeitern im Meteoriten Allende entdeckt wurde, 90 Prozent.

1. Anders, E.: Chem. Engn. News 54 (19), 27 (1976)

2. Lewis, R.S., Srinivasan, B., Anders, E.: Science 190, 1251 (1975); Anders, E, et al.: ibid. 190, 1262 (1975)

3. z.B. Nix, J.R.: CERN Report 70-30, S. 605 (1970). Leichter zugänglich ist Seaborg, G.T.: Ann. Rev. Nucl. Sci. 18, 53 (1968) 